\title{
Viability of probiotic bacteria in bioyogurt with the addition of honey from Jataí and Africanized bees
}

\author{
Luciana Albuquerque Caldeira(1), Érika Endo Alves(2), Antonia de Maria Filha Ribeiro(1), \\ Vicente Ribeiro Rocha Júnior ${ }^{(1)}$, Alciane Batista Antunes ${ }^{(1)}$, Alvimara Félix dos Reis ${ }^{(1)}$, \\ Joanni da Cruz Gomes ${ }^{(1)}$, Márcio Henrique Rodrigues de Carvalho(1) and Ruth Irene Espinosa Martinez ${ }^{(3)}$
}

\begin{abstract}
(1)Universidade Estadual de Montes Claros, Campus Janaúba, Avenida Reinaldo Viana, no 2.630, Bico da Pedra, CEP 39440-000 Janaúba, MG, Brazil. E-mail: luciana.caldeira@unimontes.br, antonia.ribeiro@unimontes.br, vicente.rocha@unimontes.br, alcianebatista@hotmail.com, alvimarafelix@hotmail.com, joannizootec@gmail.com, marzootec@gmail.com (2)Universidade Federal de Minas Gerais, Instituto de Ciências Agrárias, Campus Regional de Montes Claros, Avenida Universitária, № 1.000, Bairro Universitário, CEP $39404-547$ Montes Claros, MG, Brazil. E-mail: erikaendobr@yahoo.com.br ${ }^{(3)}$ Universidad Técnica Particular de Loja, San Cayetano Alto, Calle París, Loja, Ecuador. E-mail: rimartinez@utpl.edu.ec
\end{abstract}

\begin{abstract}
The objective of this work was to evaluate the viability of probiotic bacteria in bioyogurt with the addition of honey from Africanized and Jataí bees, in different concentrations. To prepare the fermented milk, reconstituted powdered milk and lactic acid starter culture were used. The bioyogurt was evaluated at 0,7 , 14, 21, 28, and 35 days of storage. Analyzes of $\mathrm{pH}$, titratable acidity, and selective count of the Lactobacillus acidophilus LA-5 and Bifidobacterium BB-12 microorganisms were carried out. Counting was done, respectively, on MRS agar, in aerobiosis, and MRS-LP agar, in anaerobiosis, with plates incubated at $37^{\circ} \mathrm{C}$ for 72 hours. Treatments were arranged in a completely randomized design in split plot, with five treatments: without honey; 5 and 10\% honey from Africanized bees, and 5 and 10\% honey from Jataí bees. Storage times were evaluated in the split plots. In all treatments, bioyogurt showed counts of $10^{7} \mathrm{CFU} \mathrm{g}^{-1}$ lactic acid bacteria. Probiotic cultures remained viable for 35 days under refrigeration $\left(2-4^{\circ} \mathrm{C}\right)$. The interaction between the variation factors affected the probiotic concentration in the bioyogurt. The honeys have a favorable effect on the cell counts of the evaluated microorganisms.
\end{abstract}

Index terms: Bifidobacterium, Lactobacillus acidophilus, functional food, prebiotic.

\section{Viabilidade de bactérias probióticas em bioiogurte adicionado de mel de abelhas Jataí e africanizadas}

\begin{abstract}
Resumo - O objetivo deste trabalho foi avaliar a viabilidade de bactérias probióticas em bioiogurte adicionado de mel de abelhas africanizadas e Jataí, em diferentes concentrações. Para a elaboração do leite fermentado, utilizou-se leite em pó reconstituído e fermento lácteo. O bioiogurte foi avaliado com 0, 7, 14, 21, 28 e 35 dias de armazenamento. Foram realizadas análises de $\mathrm{pH}$, acidez titulável e contagem seletiva dos microrganismos Lactobacillus acidophilus LA-5 e Bifidobacterium BB-12. As contagens foram realizadas, respectivamente, em ágar MRS, em aerobiose, e ágar MRS-LP, em anaerobiose, com placas incubadas a $37^{\circ} \mathrm{C}$ por 72 horas. Os tratamentos foram arranjados em delineamento inteiramente casualizado, com parcelas subdivididas e cinco tratamentos: sem mel; 5 e $10 \%$ de mel de abelha africanizada; e 5 e $10 \%$ de mel de abelha Jataí. Os tempos de estocagem foram avaliados nas subparcelas. O bioiogurte apresentou contagens de bactérias láticas de $10^{7}$ $\mathrm{UFC} \mathrm{g}^{-1}$, em todos os tratamentos. As culturas probióticas mantiveram-se viáveis por 35 dias sob refrigeração $\left(2-4^{\circ} \mathrm{C}\right)$. Houve efeito da interação entre os fatores de variação sobre a concentração dos probióticos no bioiogurte. Os méis têm efeito favorável sobre a contagem de células dos microrganismos avaliados.
\end{abstract}

Termos para indexação: Bifidobacterium, Lactobacillus acidophilus, alimento funcional, prebiótico.

\section{Introduction}

The concern with health and life quality has led people to eat healthier foods with some functional properties. In this scenario, the dairy industry stands out with the largest number of functional products, such as bioyogurt and other fermented milk, obtained with the addition of probiotics and prebiotics (Antunes et al., 2007; Granato et al., 2010).

The consumption of fermented milk has been based, for a long time, on yogurt traditionally
Pesq. agropec. bras., Brasília, v.53, n.2, p.206-211, Feb. 2018 DOI: 10.1590/S0100-204X2018000200009 (c) BY This is an open-access article distributed under the Creative Commons Attribution 4.0 International License 
produced with cultures of Streptococcus salivarius subsp. thermophilus and Lactobacillus delbrueckii subsp. bulgaricus. As time went by, however, the use of probiotic microorganisms, associated or not with traditional bacteria, became usual. In this sense, bioyogurt is being prepared with microorganisms that promote beneficial effects to the consumers, such as L. acidophilus and Bifidobacterium spp. (LourensHattingh \& Viljoen, 2001).

The development of probiotics is favored by prebiotics, which are selectively fermentable ingredients that promote bacteria maintenance (Wang, 2009; Bindels et al., 2015). The main prebiotics used in the food industry are oligosaccharides - especially inulin and oligofructose (Akalin \& Erisir, 2008) -, which are sugars found in most of the foods such as vegetables, fruits, milk, and honey (Dwivedi et al., 2014; García-Cayuela et al., 2014).

According to Ustunol \& Gandhi (2001), honey is a food with prebiotic activity due to the variety of oligosaccharides present in it. However, the prebiotic effect may vary with the composition of different types of honey, which is a factor that should be investigated. Crane (1985) pointed out that these variations depend on the plant species visited by the bees, on environmental conditions, and also on the bee species.

The objective of this work was to evaluate the viability of probiotic bacteria in bioyogurt with the addition of honey from Africanized and Jataí bees, in different concentrations.

\section{Materials and Methods}

The raw materials used for the preparation of the bioyogurt were: Molico (Nestle Brasil Ltda., São Paulo, SP, Brazil) skimmed powder milk; BioRich (Chr. Hansen Ind. e Com. Ltda., Valinhos, SP, Brazil) probiotic culture containing L. acidophilus LA-5, Bifidobacterium BB-12, and $S$. thermophilus; and the honeys - purchased in the retail market - from Africanized (Apis mellifera) and "stingless" Jataí (Tetragonisca angustula) bees, after pasteurization at $78^{\circ} \mathrm{C}$, for 6 min in water bath (Gonnet et al., 1964).

The $\mathrm{pH}$ from the reconstituted milk (12\%) used to make the bioyogurt was determined using the P100 benchtop pH meter (PHOX, Colombo, PR, Brazil) and by acidity titration with Dornic solution $(0.1111 \mathrm{~N} \mathrm{NaOH})$. The count of aerobic mesophilic microorganisms was performed starting at $10^{-1}$ dilution up to $10^{-5}$ decimal dilutions in peptone water. Inoculation was carried out on plate count agar (PCA), with incubation at $35^{\circ} \mathrm{C}$ for 48 hours (Silva et al., 2010).

For the characterization of the honeys, the following analyses were performed in duplicate: moisture, determined with a refractometric method using the PAL-22S digital refractometer (Atago CO., Ltd., Tokyo, Japan), specific for honey; $\mathrm{pH}$, with the P100 benchtop pH meter (PHOX, Colombo, PR, Brazil); water activity (aw), by readings in the 3TE Aqualab equipment (Meter Group, Inc., Pullman, WA, USA); and instrumental color evaluation, i.e., luminosity $\left(\mathrm{L}^{*}\right)$ and coordinates $\mathrm{a}^{*}$ and $\mathrm{b}^{*}$, using the Miniscan EZ colorimeter (HunterLab, Reston, VA, USA). The microbiological analysis was performed by yeast and mold counts, using a $10^{-1}$ dilution, with decimal dilutions up to $10^{-5}$, in peptone water. Inoculations were made on plates of acidified potato dextrose agar (PDA), with incubation at $22-25^{\circ} \mathrm{C}$, for five days (Silva et al., 2010).

For the preparation of fermented milk (bioyogurt), the skimmed powder milk was reconstituted to $12 \%(\mathrm{~m} / \mathrm{v})$ of total solids-not-fat, subjected to slow pasteurization $\left(65^{\circ} \mathrm{C}\right.$ for $\left.30 \mathrm{~min}\right)$, and then cooled $\left(42^{\circ} \mathrm{C}\right)$ for the inoculation of lactic yeast. Culturing was done by seeding lactic yeast to milk at a concentration of $400 \mathrm{mg} \mathrm{L}^{-1}$, followed by manual homogenization and incubation at $40-42^{\circ} \mathrm{C}$ for 5 hours. To obtain the treatments, the formulations of the bioyogurt were prepared as described in Table 1.

After fermentation, the bioyogurt was kept under refrigeration at $2-4^{\circ} \mathrm{C}$ for 12 hours and then analyzed after $0,7,14,21,28$, and 35 days of storage. The following analyses were carried out in duplicate in the bioyogurt: $\mathrm{pH}$, using the $\mathrm{P} 100$ benchtop $\mathrm{pH}$ meter (PHOX, Colombo, PR, Brazil); and titratable acidity, by calculating the percentage of lactic acid in the

Table 1. Raw materials and concentrations used in the different formulations of the bioyogurt.

\begin{tabular}{lccc}
\hline Treatment & $\begin{array}{c}\text { Reconstituted } \\
\text { skimmed milk (\%) }\end{array}$ & $\begin{array}{c}\text { Africanized bee } \\
\text { honey (\%) }\end{array}$ & $\begin{array}{c}\text { Jataí bee } \\
\text { honey (\%) }\end{array}$ \\
\hline 1 & 100 & 0 & 0 \\
2 & 95 & 0 & 5 \\
3 & 90 & 0 & 10 \\
4 & 95 & 5 & 0 \\
5 & 90 & 10 & 0 \\
\hline
\end{tabular}

Pesq. agropec. bras., Brasília, v.53, n.2, p.206-211, Feb. 2018 DOI: 10.1590/S0100-204X2018000200009 
sample with titration performed with $\mathrm{NaOH} 0.1 \mathrm{~N}$. For the selective count of L. acidophilus LA-5, MRS agar was used, with plates incubated at $37^{\circ} \mathrm{C}$ for 72 hours, in aerobiosis. For Bifidobacterium BB-12, counting was done on MRS-LP agar, with incubation at $37^{\circ} \mathrm{C}$ for 72 hours, in anaerobiosis, using the Anaerobac atmospheric generator (Probac do Brasil Produtos Bacteriológicos Ltda., Santa Cecília, SP, Brazil). In the two culture media, inoculation in depth was carried out with overlay. For the preparation of the MRSLP agar, $0.3 \%$ sodium propionate and $0.2 \%$ lithium chloride were used (Vinderola \& Reinheimer, 1999).

Plates with 25 to 250 colonies of $L$. acidophilus LA-5 and Bifidobacterium BB-12 were selected for the counts. The tests of Gram stain and catalase were performed to identify and confirm the colonies.

A completely randomized design arranged in split plots was used. The treatments (without honey, 5 and $10 \%$ Africanized bee honey, and 5 and 10\% Jataí bee honey) were placed in the plots, and storage times ( 0 , $7,14,21,28$, and 35 days) in the subplots. The data were subjected to the analysis of variance, and, when significant, the averages were compared by Tukey's test, at $5 \%$ probability. For the variable $\mathrm{pH}$, which, in the analysis of variance, was only affected by storage times, the regression analysis was performed.

\section{Results and Discussion}

The reconstituted powdered milk used to prepare the bioyogurt presented high acidity levels $\left(24^{\circ} \mathrm{D}\right)$ in relation to those established by legislation, i.e., between 14 and $18^{\circ} \mathrm{D}$ (Brasil, 2011). This probably occurred because of the reconstitution of the product, which was standardized to have a content of solids-notfat of $12 \%$ in skimmed milk, and of the concentration of proteins, which can acidify the medium. According to Reis et al. (2011), the increase in milk solids results in an increase in titratable acidity, due to the higher content of proteins, citrates, and phosphates. Therefore, an adjustment in the contents of milk solids favors the stability of fermented milk and improves the consistency of the product. The $\mathrm{pH}$ showed an average value of 6.7 , within the normal range for milk, which lies from 6.6 to 6.8 .

The assessment of milk microbiological quality regarding mesophilic aerobic microorganisms showed 3,200 colony-forming unity (CFU) per $\mathrm{mL}^{-1}$, within the limit permitted by law, which establishes a maximum value of $80,000 \mathrm{CFU} \mathrm{mL}^{-1}$ (Brasil, 2011). These low counts were probably due to the heat treatment to which the milk was subjected to.

The honeys differed significantly regarding $\mathrm{pH}$, water activity, moisture, $\mathrm{L}^{*}$, and the $\mathrm{b}^{*}$ color coordinate (Table 2). In addition, the honey from the Jataí bee was more acid than that from the Africanized bee. Abadio Finco et al. (2010) found that the $\mathrm{pH}$ of the Jataí bee honey varies from 3.39 to 4.63 and of the Africanized bee honey, from 3.4 to 4.2. However, the Brazilian legislation does not establish limits for $\mathrm{pH}$ values in honey. According to Crane (1985), this parameter can be directly associated with the floristic composition in the collection areas.

The moisture content of the Jataí bee honey $(26.06 \%)$ was also greater than that of Africanized bee honey $(15.43 \%)$. The law allows moisture contents of up to $20 \%$ for Africanized bee honey, and the values for Jataí bee honey were within the normal range observed in Brazil (Anacleto et al., 2009; Lira et al., 2014). This parameter can greatly affect honey quality, since greater contents favor the growth of microorganisms and may lead to undesirable honey fermentation during storage (Saxena et al., 2010). According to Silva et al. (2010), the limit of water activity for the multiplication of the majority of molds and yeasts is around 0.75 . In the present study, the values found for water activity were 0.48 for Africanized bee honey and 0.70 for Jataí bee honey.

No statistical difference was observed in the quantification of molds and yeasts. The two types of honey assessed showed average values (Table 3) below

Table 2. Characteristics of the Jataí (Tetragonisca angustula) and Africanized (Apis mellifera) bee honeys used to make the bioyogurt ${ }^{(1)}$.

\begin{tabular}{lcc}
\hline Parameter & Africanized bee honey & Jataí bee honey \\
\hline $\mathrm{pH}$ & $5.04 \mathrm{a}$ & $3.67 \mathrm{~b}$ \\
Water activity & $0.48 \mathrm{~b}$ & $0.70 \mathrm{a}$ \\
Moisture (\%) & $15.43 \mathrm{~b}$ & $26.06 \mathrm{a}$ \\
$\mathrm{L}^{*}$ & $0.07 \mathrm{~b}$ & $0.17 \mathrm{a}$ \\
$\mathrm{a}^{*}$ & $0.18 \mathrm{a}$ & $0.15 \mathrm{a}$ \\
$\mathrm{b}^{*}$ & $0.05 \mathrm{~b}$ & $0.38 \mathrm{a}$ \\
Mold and yeast $\left(\mathrm{CFU} \mathrm{g}^{-1}\right)$ & $36.6 \mathrm{a}$ & $70.0 \mathrm{a}$ \\
\hline
\end{tabular}

${ }^{(1)}$ Means followed by equal letters do not differ by Tukey's test, at $5 \%$ probability. L*, luminosity; $\mathrm{a}^{*}$ and $\mathrm{b}^{*}$, color coordinates; and CFU, colony-forming unit. 
the one of $100 \mathrm{CFU} \mathrm{g}{ }^{-1}$ allowed by legislation (Brasil, 2000). Therefore, both types are suitable for use as bioyogurt ingredients.

Regarding $\mathrm{L}^{*}$, the honey from the Jataí bee was lighter (0.17) than that from the Africanized bee (0.07), and, as to parameter $b^{*}$, Jataí bee honey had a more yellow coloring. The honeys, however, did not differ as to $\mathrm{a}^{*}$. According to the literature, Jataí bee honey has a predominance of bright tones, when compared with Africanized bee honey; the color of honeys varies according to the bee species and to factors such as mineral and flavonoid contents and Maillard reaction products (Sant'Anna et al., 2012).

Several requirements should be met for a microorganism to be classified as a probiotic, and viability is one of the most important. Viable cells should be present at the time of consumption until the last day of the validity date, at least with the minimum concentrations required by legislation (Macedo et al., 2008). The lactic acid bacteria counts in the bioyogurt were within law requirements in all treatments. According to Brazilian legislation, fermented milk must present counts of total lactic bacteria of at least $10^{6} \mathrm{CFU}$ $\mathrm{g}^{-1}$; however, the requirement for bifidobacteria alone is $10^{6}$ (Brasil, 2007). All treatments showed $10^{7} \mathrm{CFU} \mathrm{g}^{-1}$.

The effects of types of honey and of the different concentrations interacted with those of storage times, significantly affecting cell counts. Moreover, both types of honey favored L. acidophilus LA-5 and Bifidobacterium BB-12 (Table 3). The control treatment, without the addition of honey, showed the lowest concentration of $L$. acidophilus LA-5 at the end of 35 days of storage, whereas the addition of both types of honey, regardless of the concentration, favored the maintenance of L. acidophilus LA-5. This result contradicts those of Macedo et al. (2008), who did not observe honey (A. mellifera) prebiotic effect on the growth and viability of Lactobacillus spp. in milk.

Treatments 3 and 5 (10\% Jataí and Africanized bee honey, respectively), with the highest honey concentrations, had a significant favorable effect on Bifidobacterium BB-12 counts, compared with treatments 1, 2, and 4 (no honey, 5\% Jataí and 5\% Africanized bee honey, respectively). According to Silva et al. (2006), honey oligosaccharides vary according to their floral origin; therefore, the prebiotic effect of different honeys should differ.

Jan Mei et al. (2010), when evaluating B. longum BB 536 in skimmed milk with the addition of 5\% honey, reported an increase of more than three logarithmic cycles in an interval of 24 hours. Macedo et al. (2008) also found favorable effects of honey on bacterial counts in milk, with significantly higher overall average growth and viability of Bifidobacterium lineages compared with the control (without honey).

Despite their favorable effect on bacterial counts (Table 3), the studied honeys also had a detrimental effect on the viability of these microorganisms over the

Table 3. Means ( $\log \mathrm{CFU} \mathrm{mL} \mathrm{mL}^{-1}$ ) of the counts of Lactobacillus acidophilus LA-5 and Bifidobacterium BB-12 obtained in the evaluated bioyogurt during storage times ${ }^{(1)}$.

\begin{tabular}{|c|c|c|c|c|c|c|}
\hline \multirow[t]{2}{*}{ Treatment } & \multicolumn{6}{|c|}{ Storage time (days) } \\
\hline & 0 & 7 & 14 & 21 & 28 & 35 \\
\hline & \multicolumn{6}{|c|}{ Lactobacillus acidophilus LA-5 } \\
\hline Control & 7.78Aa & 7.66Aa & 7.64Aa & 7.49Cab & $7.21 \mathrm{Bb}$ & $7.28 \mathrm{Bb}$ \\
\hline Jataí bee honey ( $5 \%)$ & $7.78 \mathrm{Aa}$ & 7.70Aab & $7.78 \mathrm{Aa}$ & 7.62BCab & $7.38 \mathrm{ABb}$ & 7.54Aab \\
\hline Jataí bee honey $(10 \%)$ & 7.74Aa & 7.70Aa & $7.75 \mathrm{Aa}$ & 7.84Aa & 7.64Aa & $7.57 \mathrm{Aa}$ \\
\hline Africanized bee honey ( $5 \%)$ & $7.83 \mathrm{Aa}$ & 7.76Aab & 7.74Aab & $7.68 \mathrm{ABb}$ & $7.45 \mathrm{ABc}$ & $7.43 \mathrm{ABc}$ \\
\hline \multirow[t]{2}{*}{ Africanized bee honey $(10 \%)$} & $7.85 \mathrm{Aa}$ & 7.75Aab & 7.79Aa & 7.73ABabc & $7.60 \mathrm{ABbc}$ & $7.59 \mathrm{Ac}$ \\
\hline & \multicolumn{6}{|c|}{ Bifidobacterium BB-12 } \\
\hline Control & 7.67Aa & $7.59 \mathrm{Ba}$ & $7.53 \mathrm{Ba}$ & $7.51 \mathrm{Ca}$ & $7.53 \mathrm{Da}$ & $7.50 \mathrm{Ba}$ \\
\hline Jataí bee honey $(5 \%)$ & $7.87 \mathrm{Aa}$ & 7.86Aa & $7.85 \mathrm{Aa}$ & $7.67 \mathrm{Bb}$ & 7.64BCbc & $7.56 \mathrm{Bc}$ \\
\hline Jataí bee honey $(10 \%)$ & 7.88Aab & 7.90Aab & 7.92Aa & $7.84 \mathrm{Ab}$ & $7.84 \mathrm{Ab}$ & 7.86Aab \\
\hline Africanized bee honey ( $5 \%)$ & 7.69Aa & $7.67 \mathrm{Ba}$ & $7.60 \mathrm{Ba}$ & 7.71ABa & $7.56 \mathrm{CDa}$ & $7.52 \mathrm{Ba}$ \\
\hline Africanized bee honey $(10 \%)$ & 7.90Aab & 7.92Aa & 7.87Aab & 7.79ABcd & 7.73Bd & $7.84 \mathrm{Abc}$ \\
\hline
\end{tabular}

${ }^{(1)}$ Means followed by equal letters, lowercase in the lines and uppercase in the columns, do not differ by Tukey's test, at 5\% probability. CFU, colonyforming unit. 
storage periods. The viability of L. acidophilus LA-5 decreased in all treatments, except in that with $10 \%$ Jataí bee honey (treatment 3). Bifidobacterium BB-12 had its viability decreased in treatments 2,3 , and 5 (5 and 10\% Jataí bee honey, and 10\% Africanized bee honey, respectively). According to Cruz et al. (2011), the probiotic microorganisms in yogurt face adverse conditions during the storage period, such as stresses caused by cold, oxidation due to the exposure to oxygen, and post-acidification.

Neither treatments nor storage times influenced bioyogurt acidity. The average values observed were $0.58,0.65,0.66,0.65$, and $0.62 \%$ lactic acid, for treatments $1,2,3,4$, and 5, respectively. Most values were within the titratable acidity range of 0.6 to $2.0 \%$ lactic acid established for fermented milk by the Brazilian legislation; however, the control treatment did not comply with this minimum requirement. The interaction between microorganisms and honey types suggests that a fermentation time greater than 5 hours should be used. Regarding $\mathrm{pH}$, no significant difference was observed between treatments (Figure 1); however, storage times had a significant effect on this variable.

It is essential to control the $\mathrm{pH}$ and acidity of the product in order to avoid phase separation and great alterations in other sensory characteristics caused by high acidification (Vinderola et al., 2000). The conditions observed in the present study probably can provide a proper maintenance of the probiotic microorganisms evaluated.

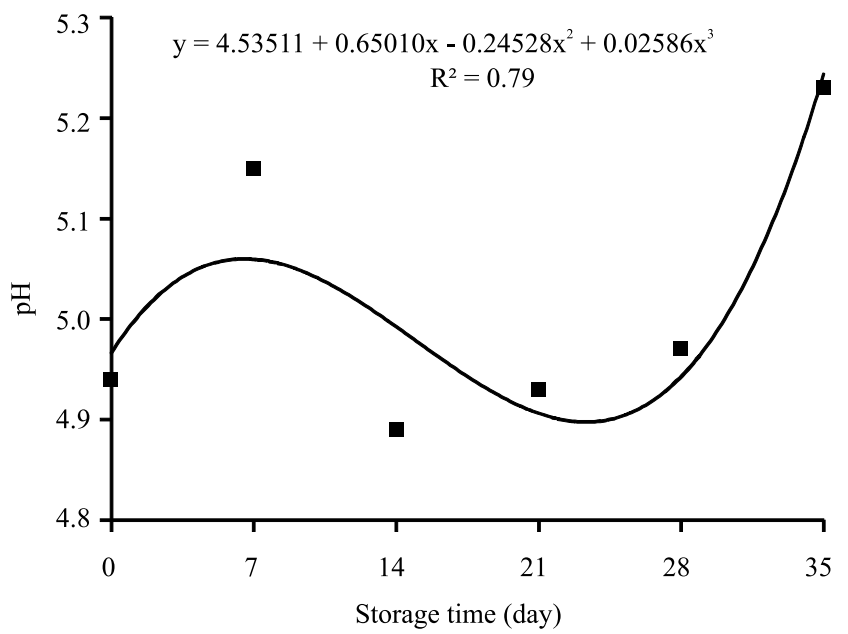

Figure 1. Bioyogurt $\mathrm{pH}$ over the period of 35 days of storage.

\section{Conclusions}

1. Both Jataí (Tetragonisca angustula) and Africanized (Apis mellifera) bee honeys favor the viability of probiotic cultures obtained with Lactobacillus acidophilus LA-5 and Bifidobacterium BB-12 in bioyogurt.

2. Both honey types provide lactic bacteria counts within the range required by Brazilian legislation, regardless of the honey concentration used, and the probiotic cultures remain viable after 35 days of storage under refrigeration $\left(2-4^{\circ} \mathrm{C}\right)$.

\section{Acknowledgments}

To Conselho Nacional de Desenvolvimento Científico e Tecnológico (CNPq), for scholarships and financial support; and to Fundação de Amparo à Pesquisa de Minas Gerais (Fapemig), for scholarship granted.

\section{References}

ABADIO FINCO, F.D.B.; MOURA, L.L.; SILVA, I.G. Propriedades físicas e químicas do mel de Apis mellifera L. Ciência e Tecnologia de Alimentos, v.30, p.706-712, 2010. DOI: 10.1590/S0101-20612010000300022.

AKALIN, S.; ERISIR, D. Effects of inulin and oligofructose on the rheological characteristics and probiotic culture survival in low-fat probiotic ice cream. Journal of Food Science, v.73, p.184188, 2008. DOI: 10.1111/j.1750-3841.2008.00728.x.

ANACLETO, D. de A.; SOUZA, B. de A.; MARCHINI, L.C.; MORETI, A.C. de C.C. Composição de amostras de mel de abelha Jataí (Tetragonisca angustula latreille, 1811). Ciência e Tecnologia de Alimentos, v.29, p.535-541, 2009. DOI: 10.1590/ S0101-20612009000300013.

ANTUNES, A.E.C.; MARASCA, E.T.G.; MORENO, I.; DOURADO, F.M.; RODRIGUES, L.G.; LERAYER, A.L.S. Desenvolvimento de buttermilk probiótico. Ciência e Tecnologia de Alimentos, v.27, p.83-90, 2007. DOI: 10.1590/S010120612007000100015.

BINDELS, L.B.; DELZENNE, N.M.; CANI, P.D.; WALTER, J. Towards a more comprehensive concept for prebiotics. Nature Reviews, Gastroenterology \& Hepatology, v.2, p.303-310, 2015. DOI: $10.1038 /$ nrgastro.2015.47.

BRASIL. Ministério da Agricultura, Pecuária e Abastecimento. Instrução Normativa $n^{\circ} 11$, de 20 de outubro de 2000. Aprova o Regulamento Técnico de Identidade e Qualidade do Mel. Diário Oficial [da] República Federativa do Brasil, 23 out. 2000. Seção 1, p. 23.

BRASIL. Ministério da Agricultura, Pecuária e Abastecimento. Instrução Normativa $n^{\circ} 46$, de 23 de outubro de 2007. Adota 
o Regulamento Técnico de Identidade e Qualidade de Leites Fermentados. Diário Oficial da União, 24 out. 2007. Seção 1, p. 4.

BRASIL. Ministério da Agricultura, Pecuária e Abastecimento. Instrução Normativa $n^{\circ} 62$, de 29 de dezembro de 2011. Aprova o Regulamento Técnico de Produção, Identidade e Qualidade do Leite Tipo A, o Regulamento Técnico de Identidade e Qualidade de Leite Cru Refrigerado, o Regulamento Técnico de Identidade e Qualidade de Leite Pasteurizado e o Regulamento Técnico da Coleta de Leite Cru Refrigerado e seu Transporte a Granel. Diário Oficial da União, 30 dez. 2011. Seção 1.

CRANE, E. O livro do mel. In: CRANE, E. Constituintes e características do mel. 2.ed. São Paulo: Nobel, 1985. p.55-80.

CRUZ, A.G.; ANTUNES, A.E.C.; FARIA, J.A.F.; CHAVES, A.C.S.D.; CARVALHO, L.M.J.; SAAD, S.M.I. Leites fermentados e iogurtes probióticos e prebióticos. In: SAAD, S.M.I.; CRUZ, A.G. da; FARIA, J. de A.F. Probióticos e prebióticos em alimentos: fundamentos e aplicações tecnológicas. São Paulo: Varela, 2011. p.271-304.

DWIVEDI, S.; SAHRAWAT, K.; PUPPALA, N.; ORTIZ, R. Plant prebiotics and human health: biotechnology to breed prebioticrich nutritious food crops. Electronic Journal of Biotechnology, v.17, p.238-245, 2014. DOI: 10.1016/j.ejbt.2014.07.004.

GARCÍA-CAYUELA, T.; DÍEZ-MUNICIO, M.; HERRERO, M.; MARTÍNEZ-CUESTA, M.C.; PELÁEZ, C.; REQUENA, T.; MORENO, F.J. Selective fermentation of potential prebiotic lactose-derived oligosaccharides by probiotic bacteria. International Dairy Journal, v.38, p.11-15, 2014. DOI: 10.1016/j. idairyj.2014.03.012.

GONNET, M.; LAVIE, P.; LOUVEAUX, J. La pasteurization des miels. Annals of Abeilles, v.7, p.81-102, 1964. DOI: 10.1051/ apido:19640201.

GRANATO, D.; BRANCO, G.F.; CRUZ, A.G.; FARIA, J. de A.F.; SHAH, N.P. Probiotic dairy products as functional foods. Comprehensive Reviews in Food Science and Food Safety, v.9, p.455-470, 2010. DOI: 10.1111/j.1541-4337.2010.00120.x.

JAN MEI, S.; MOHD NORDIN, M.S.; NORRAKIAH, A.S. Fructooligosaccharides in honey and effects of honey on growth of Bifidobacterium longum BB 536. International Food Research Journal, v.17, p.557-561, 2010.

LIRA, A.F.; SOUSA, J.P.L. de M.; LORENZON, M.C.A.; VIANNA, C.A.F.J.; CASTRO, R.N. Estudo comparativo do mel de Apis mellifera com méis de meliponíneos de diferentes regiões. Acta Veterinaria Brasilica, v.8, p.169-178, 2014. DOI: 10.21708/ avb.2014.8.3.3560.
LOURENS-HATTINGH, A.; VILJOEN, B.C. Yogurt as probiotic carrier food. International Dairy Journal, v.11, p.1-17, 2001. DOI: 10.1016/S0958-6946(01)00036-X.

MACEDO, L.N.; LUCHESE, R.H.; GUERRA, A.F.; BARBOSA, C.G. Efeito prebiótico do mel sobre o crescimento e viabilidade de Bifidobacterium spp. e Lactobacillus spp. em leite. Ciência e Tecnologia de Alimentos, v.28, p.935-942, 2008. DOI: 10.1590/ S0101-20612008000400027.

REIS, S. de M.; PINTO, M.S.; BRANDI, I.V. Efeito do teor de sólidos não gordurosos e da concentração de sacarose na acidificação de iogurte por bactérias láticas. Revista do Instituto de Laticínios Cândido Tostes, v.66, p.34-39, 2011.

SANT'ANA, L.D'O; SOUSA J.P.L.M.; SALGUEIRO, F.B.; LORENZON, M.C.A.; CASTRO, R.N. Characterization of monofloral honeys with multivariate analysis of their chemical profile and antioxidant activity. Journal of Food Science, v.71, p.135-140, 2012. DOI: 10.1111/j.1750-3841.2011.02490.x.

SAXENA, S.; GAUTAM, S.; SHARMA, A. Physical, biochemical and antioxidant properties of some Indian honeys. Food Chemistry, v.118, p.391-397, 2010. DOI: 10.1016/j. foodchem.2009.05.001.

SILVA, R.A.; MAIA, G.A.; SOUSA, P.H.M.; COSTA, J.M.C. Composição e propriedades terapêuticas do mel de abelha. Alimentos e Nutrição, v.17, p.113-120, 2006.

SILVA, N. da; JUNQUEIRA, V.C.A.; SILVEIRA, N.F. de A. Manual de métodos de análise microbiológica de alimentos e água. 4.ed. São Paulo: Varela, 2010. 624p.

USTUNOL, Z.; GANDHI, H. Growth and viability of commercial Bifidobacterium spp. on honey-sweetened skim milk. Journal of Food Protection, v.64, p.1775-1779, 2001. DOI: 10.4315/0362028X-64.11.1775.

VINDEROLA, C.G.; BAILO, N.; REINHEIMER, J.A. Survival of probiotic in Argentina yogurts during refrigerated storage. Food Research International, v.33, p.97-102, 2000. DOI: 10.1016/S0963-9969(00)00011-9.

VINDEROLA, C.G.; REINHEIMER, J.A. Culture media for the enumeration of Bifidobacterium bifidum and Lactobacillus acidophilus in the presence of yoghurt bacteria. International Dairy Journal, v.9, p.497-505, 1999. DOI: 10.1016/S09586946(99)00120-X.

WANG, Y. Prebiotics: present and future in food science and technology. Food Research International, v.42, p.8-12, 2009. DOI: 10.1016/j.foodres.2008.09.001. 